\title{
Research on Influence Factors of Rate Fluctuation of Bond Repurchase in Financial Industry
}

\author{
Tanxin Guo \\ College of Management and Economics, Tianjin University, Tianjin, 300072, China
}

Keywords: Inter-bank bond repurchase rate, Repurchase market, Inter-bank offered rate, Influence factors

\begin{abstract}
Inter-bank bond repurchase market plays an important role in China's financial market, and pledged repo is the largest and most active trading type in the inter-bank bond repurchase market. The inter-bank bond repo market has been established for more than twenty years since its establishment. The study of its influencing factors has always been a hot issue in the financial field. This paper expounds the background, research significance, development process and present situation of bond repurchase market, and analyzes the factors affecting the inter-bank bond repurchase interest rate.
\end{abstract}

\section{Current Situation of Bond Repurchase Market}

According to statistics, by the end of 2016, the settlement amount of the bond market, bond repurchase transactions is 963 trillion yuan, an increase of $43 \%$; the amount of repurchase transaction settlement market was 839 trillion yuan, an increase of 43\%. It can be seen that the bond repo market transactions accounted for $87 \%$ of the trading volume, indicating China's bond repo market has become the main bond market, the main place of market participants for short-term financing and liquidity management, the central bank open market operations and an important platform to realize the transmission of monetary policy.

\section{Existing Problems of Inter-Bank Bond Market}

Limitations of Market Participants. At the beginning of the interbank bond repurchase market, the participants were limited to commercial banks. With the continuous reform and development, the scope of market participants has been expanded, and currently mainly banks, securities companies, Asset management companies and other non-banking financial institutions. However, compared with the exchange repurchase market, the participants in the inter-bank bond repurchase market still have limitations, and the non-financial institutions cannot enter the market transaction. It limits the further expansion of the interbank bond market.

Credit Risk, Interest Rate Risk and Other Risks. Although the inter-bank bond repo market is developing rapidly and the participants are constantly expanding, the credit risk is also increasing. Because the participants are driven by interest, the cases of both parties violating repurchase transactions emerge endlessly, resulting in immeasurable credit risk. With the rapid development of the bond market and the increase of the market scale, the proportion of the bond assets in the market participants is rising, which will bring potential interest rate risk.

Illiquidity of Inter-Bank Bond Market. In the past twenty years, the volume of China's interbank bond market has risen significantly, mainly due to the growth of the bond stock. Generally speaking, the liquidity of China's interbank bond market is still weak. By comparing the turnover index between China and other developed countries in the same period, we find that the market of developed countries is much higher than that of China's interbank bond market in terms of liquidity. 


\section{Empirical Analysis of Influence Factors of Inter-Bank Bond Repurchase Rate}

Index Selection and Data Sources. This paper selects seven days inter-bank pledge repo rate as the research object. The most commonly used interbank lending rates in China are the Shanghai interbank offered rate (Shibor) and the China interbank offered rate (Chibor). There are differences in the formation mechanism, market participants and trading volume. Therefore, this paper uses Shibor to represent the interbank offered rate, and also chooses the seven days Shanghai interbank offered rate as an impact variable. Capital supply and demand changes in the money supply affect the currency market changes, the increase in money supply will be made in the research of economics, is usually used for the money supply growth rate to changes in the money supply, so this paper choose money supply M1 with specific growth rate as the impact of variables.

Establishment of Thermotical Model. After determining the influencing factors, the model of the research object was constructed. The seven days period, the inter-bank bond pledged repo rate can be expressed as: seven days of the inter-bank bond repo rate $=\mathrm{F}$ (the seven days period, the Shanghai interbank offered rate, money supply M1 growth rate) expressed as a mathematical model:

\section{R007=F (SH07, M1, e) (1)}

Among them, e is a random error term, representing other factors that may affect the seven days interbank bond repo weighted average interest rate not included in the function. Functions include explanatory variables, explanatory variables and random error terms.

In order to study the impact of 2 explanatory variables on the weighted average interest rate of seven days inter-bank bond repo, this paper uses multiple regression analysis to do empirical analysis, and constructs the linear regression model as follows:

$$
\mathrm{R} 007=b 0+b 1 S H 07+b 2 M 1+m
$$

Among them, b0 is a constant, R007 for a seven days period of inter-bank bond pledged repo weighted average interest rate of SH07 for seven days, the Shanghai interbank offered rate, M1 money supply growth rate of M1, $\mathrm{m}$ on behalf of random error.

\section{Empirical Test Process.}

Table 1.Basic statistical properties of the variables

\begin{tabular}{|l|c|c|r|}
\hline Category & R007 & SH07 & M1 \\
\hline Mean & 3.292501 & 3.227569 & 12.83333 \\
\hline Median & 3.231552 & 3.197070 & 9.800000 \\
\hline Maximum & 7.020000 & 6.797842 & 38.960000 \\
\hline Minimum & 1.470000 & 1.468920 & 1.200000 \\
\hline Standard deviation & 1.007023 & 1.020734 & 8.640651 \\
\hline Skewness & 0.785555 & 0.751637 & 0.880116 \\
\hline Kurtosis & 4.185847 & 3.741416 & 2.970057 \\
\hline
\end{tabular}

It can be seen from Table 3.1 that both the repo rate and the interbank offered rate in China have the property of right deviation. The skewness of M1 is greater than 0 , and the kurtosis is close to 3, which indicates that the growth rate of money supply M1 is also right skewed. 


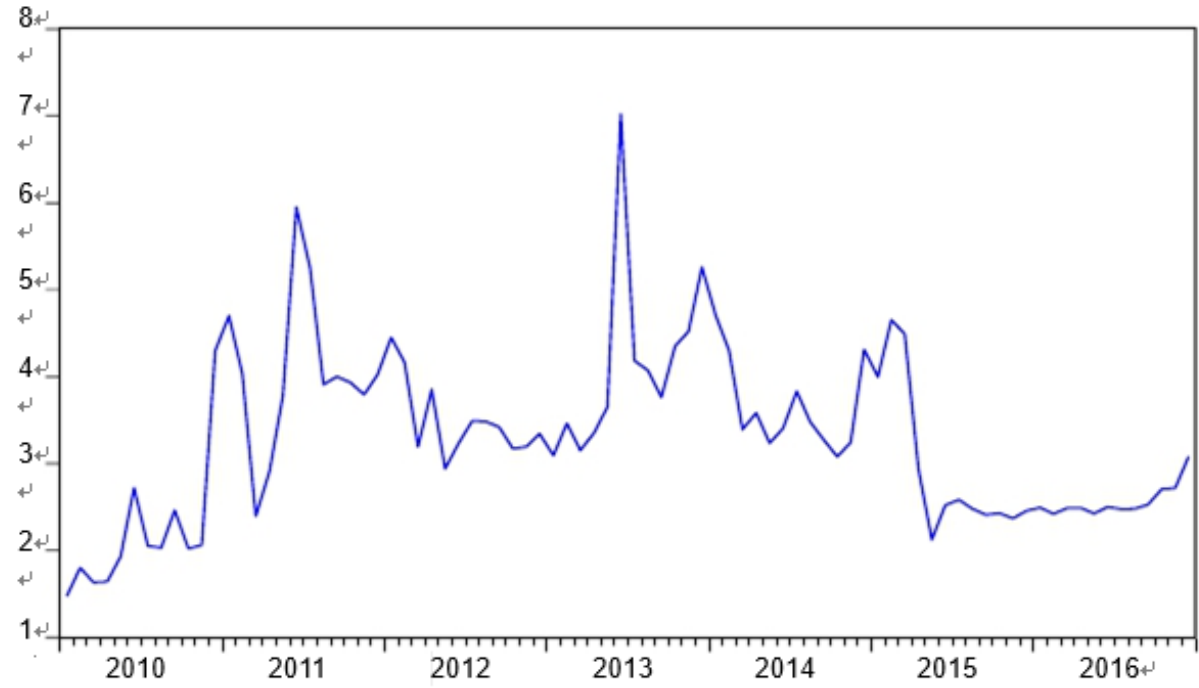

Figure 1. Change chart of 17 days inter-bank bond repo rate

The span of the horizontal axis in Figure 1 is from January 2010 to December 2016, and the longitudinal axis is the weighted average interest rate of seven days inter-bank bond repurchase.

(1) unit root ADF (Augment Dickey-Fullertest) test for the three groups of data sequence ADF test results are shown in the table below:

Table 2. Inspection result of ADF unit root of original sequence

\begin{tabular}{|l|r|r|r|l|}
\hline Variable & $10 \%$ critical value & ADF inspection value & P value & Result \\
\hline R007 & -1.614204 & -0.859692 & 0.3406 & Non-stationary \\
\hline SH007 & -1.614204 & -0.926883 & 0.3122 & Non-stationary \\
\hline M1 & -3.159372 & -2.428262 & 0.3626 & Non-stationary \\
\hline
\end{tabular}

Through the unit root test of the original sequence, the results show that the three variables selected in this paper are not stable. Next, the three variables are dealt with first order differential processing and ADF test, and the results are shown in Table 2:

Table 2. Inspection result of ADF unit root of the original sequence after the first order difference

\begin{tabular}{|l|r|r|r|l|}
\hline Variable & $10 \%$ critical value & ADF inspection value & P value & Result \\
\hline $\mathrm{D}$ (R007) & -2.586351 & -8.429975 & 0.0000 & Stationary \\
\hline $\mathrm{D}$ (SH007) & -2.586351 & -8.090695 & 0.0000 & Stationary \\
\hline $\mathrm{D}$ (M1) & -2.586351 & -10.76778 & 0.0001 & Stationary \\
\hline
\end{tabular}

It can be seen from the above test results, R007, SH07, M1 are non-stationary series, but the first difference is stationary, so R007, SH07, M1 are first-order single whole sequence, there is a cointegration relationship in theory.

Table 3. Result of Johansen co-integration test

\begin{tabular}{|l|r|r|r|r|}
\hline Original hypothesis & \multicolumn{1}{|c|}{ Eigenvalue } & Max-Eigen value & $\begin{array}{l}5 \% \text { critical } \\
\text { value }\end{array}$ & \multicolumn{1}{l|}{ P value } \\
\hline No cointegrating vector & 0.296396 & 28.47473 & 22.29962 & 0.006 \\
\hline One cointegrating vector at most & 0.160873 & 14.20684 & 15.89210 & 0.0903 \\
\hline Two cointegrating vectors at most & 0.010349 & 0.842668 & 9.164546 & 0.9697 \\
\hline
\end{tabular}

We use the least squares method (OLS regression) to estimate the model and the result is shown in Table 4. 
Table 4. Model estimation result of original sequence

\begin{tabular}{lllll}
\hline \hline \multicolumn{1}{c}{ Variable } & Coefficient & \multicolumn{1}{c}{ Std. Error } & t-Statistic & Prob. \\
\hline C & 0.051343 & 0.067861 & 0.756598 & 0.4515 \\
M1 & 0.002698 & 0.001831 & 1.473663 & 0.1444 \\
SH07 & 0.993483 & 0.015497 & 64.10881 & 0.0000 \\
\hline \hline & 0.987014 & Mean dependent var & 3.292501 \\
R-squared & 0.986693 & S.D. dependent var & 1.007023 \\
Adjusted R-squared & 0.116167 & Akaike info criterion & -1.432522 \\
S.E. of regression & 1.093069 & Schwarz criterion & -1.345707 \\
Sum squared resid & 63.16590 & Hannan-Quinn criter. & -1.397623 \\
Log likelihood & 3078.135 & Durbin-Watson stat & 1.567112 \\
F-statistic & 0.000000 & & \\
Prob(F-statistic) & & & \\
\hline \hline
\end{tabular}

From the data shown in table 3.6, we can see that the P value corresponding to M1 is $0.1444>0.1$, which indicates that it is not significant at the significance level of $10 \%$, so the model cannot explain the relationship between variables. After the original sequence is regressed, the residual sequence (ECM) is obtained, and the unit root test (ADF) is used for the residual sequence,

The results show that $\mathrm{P}$ value is 0.0003 , so the residual sequence is obtained after the return of the original sequence is stationary, so the seven days inter-bank bond pledged repo weighted average interest rate (R007), Shanghai interbank offered rate (SH07), money supply M1 growth rate (M1) as part of the test results as there is a cointegration relationship.

The sequences R007, SH07 and M1 were processed by first order difference, and the sequences DR007, DSH07 and DM1 were obtained. The sequence DR007, DSH07, DM1 and ECM (-1) were processed by linear regression, and the results were shown in Table 5:

Table 5. Model estimation result of original sequence after the first order difference

\begin{tabular}{|c|c|c|c|c|}
\hline Variable & Coefficient & Std. Error & t-Statis tic & Prob. \\
\hline $\mathrm{C}$ & 0.004032 & 0.012478 & 0.323119 & 0.7475 \\
\hline DM1 & 0.011106 & 0.004790 & 2.318598 & 0.0230 \\
\hline DSHO7 & 1.010336 & 0.016870 & 59.88851 & 0.0000 \\
\hline $\operatorname{ECM}(-1)$ & -0.874300 & 0.121545 & -7.193195 & $\underline{0.0000}$ \\
\hline R-s quared & 0.979238 & \multirow{7}{*}{\multicolumn{2}{|c|}{$\begin{array}{l}\text { Mean dependent var } \\
\text { S.D. dependent var } \\
\text { Akaike info criterion } \\
\text { Schwarz criterion } \\
\text { Hannan-Quinn criter. } \\
\text { Durbin-Wats on stat }\end{array}$}} & 0.019388 \\
\hline Adjusted R-s quared & 0.978449 & & & 0.770772 \\
\hline S.E. of regression & 0.113151 & & & -1.473201 \\
\hline Sum squared resid & 1.011442 & & & -1.356631 \\
\hline Log likelihood & 65.13785 & & & -1.426370 \\
\hline F-s tatis tic & 1241.993 & & & 1.858060 \\
\hline Prob(F-s tatis tic) & 0.000000 & & & \\
\hline
\end{tabular}

By the results of Table 5, the coefficients of the equation are dealt with by the first order differential operation. The regression equation obtained by the error correction model is shown as follows:

DR007 $=0.004032+0.011106 \mathrm{DM} 1+1.010336 \mathrm{DSH} 07-0.874300 \mathrm{ECM}(-1)(5)$ (0.323119)(2.318598)(59.88851) (-7.193195)

The short-term correction coefficient is significant. The error correction reflects the short-term error correction capability of the model.

Empirical Test Results. Through the establishment of the model, this paper comes to the conclusion that there is a short-term dynamic and long-term equilibrium relationship between R007, SH07 and M1. The analysis of the factors affecting the weighted average interest rate of the 7 day inter-bank bond repo is as follows:

R007 was positively correlated with SH07, and SH07 had a higher impact on R007. In the long-term equilibrium equation, interest rate has a positive impact on the inter-bank bond repo 
interest rates down to 7 day period of the product as an example of the Bank of Shanghai, the long-term impact coefficient was 1.805392, suggesting that other factors unchanged in the case of SH07, each increase or decrease of one percentage point, R007 the same direction will rise or fall by 1.805392 percentage points, indicating the relationship more closely, SH07 has great effect on the change of R007. According to the above analysis theory, through the empirical test part of the results prove that the offered rate of this study is that the inter-bank bond pledged repo weighted average interest rate has a significant positive effect between banks in Shanghai.

R007 was positively correlated with M1, and M1 had less influence on R007. The money supply M1 growth rate on the 7 day period is positively related to the inter-bank bond pledged repo weighted average interest rate, the money supply M1 year-on-year growth rate of positive fluctuations, the inter-bank bond pledged repo weighted average interest rate will correspondingly upward. This may be due to the fact that money supply cannot only reflect the strength of market liquidity, but also affect the price level of capital and the expectation of market participants for capital flow. The money supply M1 growth rate is actually a double impact on the inter-bank bond pledged repo weighted average interest rate, a monetary growth rate would lead to an increase in the supply of money market funds, then the fund price decline; on the other hand the rising rate of monetary growth means that the rise in the price level, the price of capital index the inter-bank bond repo rate will rise. The two effect is the opposite. The results of this study show that the growth rate of money supply M1 has positive impact on the inter-bank bond repo rate.

\section{Research Conclusions and Corresponding Suggestions}

Research Conclusions. From the three aspects of the money market, capital market and money market, this paper selects seven days Shanghai interbank offered rate (SH07), money supply M1 growth rate (M1) of two representative factors for empirical analysis. According to the empirical cointegration test and error correction model according to the results of the seven days period of Shanghai interbank offered rate (SH07), money supply M1 growth rate (M1), the seven days period, the inter-bank bond pledged repo weighted average interest rate (R007) between the short-term and long-term equilibrium relationship.

Corresponding Suggestions. The interest rate in the inter-bank bond market is of great significance to China's monetary policy. The central bank can only adjust the Shibor through the bond repurchase transactions, and use the relevant monetary policy related to the repo rate to achieve the purpose of regulating the benchmark interest rate. With the rapid development of inter-bank bond market, its scale is constantly expanding. Perfecting the tools to avoid the interest rate risk can promote the enthusiasm of the market maker, and improve the liquidity of the market.

\section{References}

[1] Huang Muyang. An Empirical Analysis oftheDifferencebetweenthe Inter-Bank Bond Repo Rate andShibor [J].Journal of East China Normal University (PhilosophyandSocialSciences), 2007, 39(6): 114-116.

[2] Wu Xiongwei, Xie Chi. ARCH/ GARCH Models for Rate in China Inter-Bank Bond Marketand Analysis on Its Volatility [J]. Systems Engineering, 2002, 20(5):88-91.

[3] Yuan Qin, Zhang Can. The Process and SignificanceofOpeningUpofthe Inter-bank Bond Market [J]. The Chinese Banker, 2015(9): 64-65.

[4] XuXiaohua, Chen Qi. Different Price Responses Between SSE Bond Market and Inter-bank Bond Market— Based on thePerspectiveOftheImportantAnnouncements [J]. 2014(6): 59-68. 